\title{
ДУХОВНО-ПЕРСОНАЛІСТСЬКІ АСПЕКТИ ФІЛОСОФСЬКОЇ СПАДЩИНИ ОЛЕКСІЯ КозЛОВа I СЕМЕНА ФРАНКА
}

\section{P.М. Вербова}

Дослідження феномена персоналізму в українській філософській думці $е$ надзвичайно актуальним, адже його ідеї та власне сам спосіб осмислення світу є питомим для національних ментально-світоглядних засад. Зокрема нагальною $є$ проблема внутрішнього світу людини, духовності українського народу, дослідження моральної філософії та її впливу на свідомість особи. Метою даного дослідження є осмислення філософських поглядів персоналістських доктрин Семена Франка та Олексія Козлова, окреслення поняття моральної філософії, її предмету та значення для критико-персоналістичної метафізики.

Для європейської філософії другої половини XIX століття характерною була «спрямованість на історію», що не зводилася до позитивістської формули історичного релятивізму, але репрезентувала суттєві зміщення в «ціннісних орієнтаціях» філософського пізнання, так звані «повернення назад». Визначальним у цьому відношенні було повернення до Канта, проголошене Лібманом і підхоплене напрямком неокантіанства. Що стояло за розумовим потягом, який викристалізувався у заклику «назад до Канта!»? Зафіксуймо кілька мотивів. Насамперед - трансцендентальне витлумачення пізнання як обгрунтованого у своїй предметності та іманентно обумовленого у фактичному здійсненні. Пов'язана 3 появог так званого «антиметафізичного» типу думання, џя тенденція спрямовувала перехід від агностично зорієнтованої позиції раннього неокантіанства (80-90 pp. XIX ст.) до розуміння дійсності як постулату мислення, конституативну діяльність якого ін- 
терпретували в термінах антиципації не тільки форми, але і змісту можливого досвіду.

Проте діалог 3 Кантом мав і інший аспект. Йдеться про спробу реабілітації метафізичної проблематики через аналітичне опрацювання та критичну перевірку внутрішніх підвалин метафізики. Це було повернення до сутнісних джерел Кантової думки. За змістовою визначеністю нова течія тяжіла до «метафізики суб'ективності», що біля їі витоків стояв Г. Лейбніц. Головні риси метафізичної настанови, яка становила підгрунтя експлікації лейбніцівських інтуїцій на спаді XIX століття були:

1) руйнування уявлення про дійсність як самодостатне зовнішне існування, відмова від онтологічного пріоритету речовості як чуттевої даності;

2) постулювання того, що багатоманітний зміст пізнавальної реальності детермінований сутністю і структурою внутрішнього досвіду;

3) дезінтелектуалізація та індивідуалізація внутрішнього досвіду.

Початок тут було покладено філософсько-психологічними студіями Гербарта та працями Лотце, який створив оригінальну систему телеологічного ідеалізму. Радикальної загостреності ідея реформації у метафізиці набула у Густава Тейхмюллера (1832-1888) та його учнів Є. Боброва і Я. Озе. У цій же шерензі стоїть і Олексій Олександрович Козлов (1831-1900), київський прибічник неолейбніціанства.

Щодо характеру міркування, особливостей бачення головних проблем метафізики, О. Козлова цілком природно розглядати як представника Київської школи філософії, до якої належали О. Новицький, С. Гогоцький, П. Юркевич, О. Гіляров, Г. Челпанов. Цікаво, що сам О. Козлов опинився в Киеві випадково, за збігом обставин. У 1875 році він виїхав до Франції, поклавши назавжди залишити Росію, i вже піл час перебування в Парижі несподівано одержав повідомлення від київського професора Котляревського, свого колишнього університетського товариша (О. Козлов закінчив філологічний факультет Московського університету), котрий пропонував йому приват-доцентуру з філософії у Києві. На той час О. Козлов, чиє знайомство з філософією почалося з Шопенгауера і Гартмана, вже мав низку статей і одну спеціальну працю «ілософські етюди». Одначе як професіональний філософ він сформувався саме в Києві, де пройшов шлях від приватдоцента до ординарного професора університету [4, с. $138-155]$.

Вельми прикметна його полеміка з М. Гротом 3 приводу визначення предмета філософії та тї наукового статусу. М. Грот тримався тієї думки, що проблематика філософії вичерпуеться суто психологічними 
питаннями, і присвятив їм обидві свої дисертації. Він був переконаний: наука, яка мала на меті синтезувати досягнення всіх галузей знання для побудови єдиної картини світу - просто неможлива. Та й чи потрібна вона? Хіба «могла б замінити філософська система про світ рекомендації здорової гігієни та результати нормального виховання?» $[2$, c. 15$]$. Це риторичне запитання М. Грота є дуже промовистим щодо інтелектуальної ситуації, в якій Козлову доводилось обстоювати свої ідеї.

Постійно наголошуючи на тому, що філософське пізнання за сутністю і цілями принципово відрізняється від конкретно-наукового, О. Козлов намагався спростувати погляд на філософію, що зводить ïi до «загальної назви» для кола спеціальних наукових дисциплін (М. Грот). Логіка його міркувань така. По-перше, самий факт існування конкретних наук спонукає ставити питання про «знання взагалі та його можливості», відповідь на яке виходить за межі компетенції позитивної науки як такої. Дослідження «загальних засад і форм будь-якого знання» і е справою філософії як універсальної «науки про науку». По-друге, філософія е вченням про зв'язок і співвідношення предметів окремих наук. Її завдання також - з'ясувати природу, походження i значення понять, якими оперує наука, покладаючи їх уже даними. I нарешті, по-трете, філософія $є$ наука, що розглядає «едність усіх явищ світу як основу для практичної діяльності людини». «Вже цього достатньо аби відкинути всі сумніви щодо необхідності і правомірності їі існування» $[2$, с. 20$]$.

Засадничу інтенцію О.Козлова найкраще схоплюе позначення «плюралістичний субстанціоналізм» як різновид персоналізму. Термін «персоналізм» у тому розумінні, яке тут мається на увазі, вперше з'являється у Тейхмюллера, котрий ідентифікував його зі своїм ученням про «Я». Але, за слушним зауваженням Озе, персоналізм можна розглядати більш узагальнено - як інтегральну світоглядну схему, що перебуває у контрастуючому зв'язку 3 «проективізмом» традиції і відповідним «стереотипом» дійсності. Таким $\varepsilon$ перше фундаментальне припушення «критико-персоналістичної метафізики», де лише «Я» має самостійність субстанційного буття, самототожність, що проходить через усі складові свідомості. Наявність цієї засадничої настанови у теоретичних побудовах О. Козлова і дозволяе нам витлумачувати його філософію як персоналістичну [3, с. 284].

Будучи переконаним, що вихід із духовної кризи суспільства можна знайти тільки в царині філософії, О. Козлов розпочав свою діяльність у цьому напрямі зі спроб відновити в правах філософію, 3 виступів 
проти позитивістських спроб замінити її конкретними науками. Проблема правомірності філософії як самостійної галузі знання зводилася передусім до з'ясування ії предмета й методу. Філософія завжди мала свій специфічний предмет дослідження, який не може бути зведеним до предметів інших наук. Це саме стосуеться й методу.

Предметом філософського пізнання, вважае О. Козлов, завжди може бути тільки один світ, а філософія є наукою про світ як суще. Визначаючи коло питань, які входять у предмет філософії, через зіставлення $\dddot{1}$ з конкретними науками, він доводить, що кожна конкретна наука, маючи, справу зі специфічним предметом дослідження, не може ставити й розв'язувати питання про предмет знання взагалі. Для постановки та вирішення цього питання потрібно вийти за межі спеціального знання про той чи інший предмет і проаналізувати елемент, тотожний усім наукам, а саме: загальні начала та форми всякого знання чи всякої науки. Це дослідження, за переконанням О. Козлова, й становить завдання особливої науки - філософії як науки про науку, про знання взагалі. Іншими словами, філософія - це наука про всі предмети спеціальних наук 3 огляду їх тотожності та належності до єдиного пілого. Вона виступає регулюючим началом у науках, коли йдеться про зв'язок між предметами деяких чи всіх існуючих у даний період наук. Водночас сама філософія завжди залежала й продовжуе залежати від рівня розвитку конкретних наук, той чи інший стан яких виступає однією із суттєвих умов успішного розвитку філософії.

Проте О. Козлов не обмежуеться таким тлумаченням філософії, а розглядае їі (залежно від виконуваних функцій) як науку, що досліджує природу, походження та значення основних понять окремих наук, як науку про зв'язок між усіма явищами світу. Отже, філософія - це наука про світ, його пізнання і його відношення до пізнаючого суб'єкта. Що ж являе собою запропонований О. Козловим варіант філософії? Це був один із різновидів персоналізму - панпсихізм [3, с. 284]. В основу концепції була покладена ідея духовної субстанції, яку людина усвідомлюе в своему внутрішньому «я». Навколишній світ $\boldsymbol{\varepsilon}$ не чим іншим, як сукупністю станів свідомості пізнаючого суб'єкта. Субстанціальна єдність цих станів здійснюється в самому суб'єкті. Матеріальний же світ сам по собі не являе ніякої реальності (подібно до того, як нереальні простір і час), він $\boldsymbol{\epsilon}$ лише знаками духовних субстанцій як єдино в собі сущого буття. Останне, вважав О. Козлов, $є$ поняття, зміст якого складається із знання про нашу субстанцію, форми їі діяльності й зміст цих форм у їхній єдності та відношенні однієї до другої. Світ являє собою не що інше, як лише систему взаємодіючих субстанцій. Він 
існуе не в просторі й часі, а в свідомості пізнаючого суб'єкта. Він не розвивається в часі, позаяк сама ідея часу повністю зникає в Богові.

Загальнофілософською позицією О. Козлова визначалася і його гносеологічна позиція. Вказуючи на цей зв'язок, він підкреслював, що та чи інша філософська система пояснюе можливість і факт пізнання взагалі, можливість осягнення істини, її критерій залежно від своїх вихідних засад. Стосовно системи самого О. Козлова, таке співвідношення означало, що пізнання існуе винятково в голові, в духові, в свідомості індивідуальної особи. Свідомість - це щось цілком індивідуальне, а основним фактором пізнання виступає субстанціальна єдність пізнаючих істот, які перетворюють свідомість із ірраціональної множинності на осмислену едність. Свідомість дана людині від природи, а категорії пізнання $\epsilon$ не чим іншим, як продуктами мислячого «я».

Панпсихізм О. Козлова був по суті ідеалізмом спіритуалістичного типу. Він являв собою своерідну реакцію на банкрутство основоположних засад класичного ідеалізму, зокрема гегелівського панлогізму, де індивідуальне цілком підпорядковувалося загальному. Питання про буття вперше було поставлене О. Козловим у «Філософських етюдах» 1880 року, де він, розрізняючи поняття буття і світу, вказуе, що буття не можна вважати дійсним предметом філософії. Світ $\epsilon$ те, у понятті чого відбувається синтез речей, явищ, подій як таких, що перебувають у закономірному зв'язку й утворюють нерозривну едність. При конструюванні поняття світу значення межового об'єкта репрезентації набуває вся сукупність доступного пізнанню, що не вичерпується актуалізованим змістом досвіду. А буття - то $\varepsilon$ «формальна умова синтезу», що його здійснюе пізнання. Ця беззмістовність $\boldsymbol{e}$ «чистою можливістю єдності» - коли $\dddot{1}$ не засвідчено реальним актом мислення, вона $є$ ніщо для пізнання. «Чисте буття» не може забезпечити необхідної обгрунтованості «судженням існування», позаяк останні фіксують не лише те, що $є$ «пустою можливістю», констатує О. Козлов [4, с. 184]. Одначе чи вирішуеться у такий спосіб фундаментальна проблема, пов'язана з самим «суттевим» у бутті? Очевидно, що ні. Адже запропонований критерій є суто тавтологічним i «байдужим до істини», бо дозволяє, приймати в єдність пізнання будь-який можливий зміст, даний такою ж мірою, як і протилежний. Акцент на формальності поняття «буття» означав лишень: у бутті не знайдено нічого, що надавало б йому незмінної самототожності, сталості у власній конкретній сутності.

Метафізика особистості - це насамперед зв'язок людини з абсолютним началом як усеєдністю. В цьому бачиться природа внутрішнього, духовного, істинного буття. Біологічна і соціально-політична сторони 
людини під цим кутом зору є зовнішнім, вторинним хоча її необхідним, але все-таки відносним моментом і1ї сутності. Застосування до суспі.льства ідеї всеєдності начебто завершує метафізичний портрет особистості у її соборній, симфонічній єдності з іншими. Філософія ж-особистісне знання, автономне творче існування (М. Хайдеггер); в такому ракурсі дослідження метафізики особистості, пізнання самого себе, а через себе і - світу, е специфічно філософським методом пізнання. До тих, хто блискуче володів цим методом, хто глибоко та оригінально опрацьовував цю проблематику, належить Семен Людвігович Франк $(1877-1950)$.

Наріжним каменем концепції С. Франка була проблема особистості-як поєднання абсолютно-загального з конкретно-індивідуальним, як ідеально-реального буття, сплаву божественного творіння і свободи волі, як «божества людини» (Геракліт). Уже в ранній публіцистиці він ставить цю проблему у центрі філософії: «У нашому філософсько-політичному світогляді ми виходимо з ідеї особистості як носія і творця духовних цінностей, здійснення яких в суспільно-історичному житті створюе зміст культури і $е$ найвищим і останнім завданням політичного будівництва» [5, с. 69]. Мислитель назавжди зберіг вірність цій стрижневій ідеї, будуючи свої погляди 3 «незвичайною єдністю» $[1$, c. 43-44].

У ранній період творчості С. Франк дотримується традиційного ліберального світогляду, заснованого, проте, на релігійному, а не секуляризованому грунті. Ідея особистості дістає безумовний пріоритет перед ідеєю держави (будь-якої соціальної спільноти), оскільки особистість $€$ «жива і вічна лабораторія духовної творчості», «єдина на землі реальна точка, в якій і через яку діє божественний дух» [5, с. 59]. Деяка однобічність у трактуванні автономії особистості, в поеднанні раціональних та ірраціональних начал суспільного життя, властива взагалі ліберальному світоглядові, виявляється і в молодого публіциста. Але його споконвічний лібералізм, який ще не отримав філософсько-онтологічного обгрунтування і політично-консервативного забарвлення, завдяки свіжим релігійно-духовним витокам набуває цілком вагомих форм - особливо в критиці деспотизму, в підході до ідеї правової держави й теорії природних прав особистості, які дістали практичне вираження в його проекті «Засновницького закону про вічні й невід'ємні права російських громадян» (1906 р.) [1, с. 43-44].

Висувається потреба в глибшому випрацювані накреслених раніше аспектів метафізики особистості. Таку розробку ми знаходимо в пізніх працях С.Франка i, насамперед, - в ученні про Неосяжне. В 
однойменній книзі, яка містить цілісну філософську систему, він рішуче опонуе раціоналізму й позитивізму. Хоча філософія С. Франка не $є$ абсолютно ірраціоналістичною або агностицистичною, вона, по суті, стверджуе, що поряд із раціонально-пізнаваною стороною буття, яка становить предмет наукового знання і виражаеться в поняттях, існуе ірраціонально-неосяжна, така, що репрезентуе предмет власне філософського знання.

Ця сторона не виявлена в поняттях і може відкриватися лише безпосередньому, живому запитуванню. Більше того, ця сторона $\epsilon$ по суті, підгрунтям реальності, її «материнським лоном», де зароджується і з якого береться все раціональне, осяжне, цебто предметний світ. Це безумовне буття $\varepsilon$ «щось», яке, хоча й містить у собі все мислиме «що», але само не $\epsilon$ ніяке визначене «щось», не будучи, проте, через це беззмістовним «ніщо». Таке буття, чия сутність збігається з його наявністю, осягається умудреним невіданням, цебто усвідомленням його неосяжності, що можливе тільки за допомогою трансраціонального пізнання, через принцип антиномічного монодуалізму [1, с. 43-44].

Звертаючись у цьому зв'язку до глибинних пластів духовних основ особистості, С. Франк гадае, що уявлення про абсолютну, цілковиту пізнаваність світу, про завершеність і закінченість нашого пізнання, про можливість підвести весь світ, що залишаеться поза нашим поглядом, під уже відомі визначення і поняття, $\epsilon$, по суті, невиправданим обмеженням поля життя та пізнання нашими інтересами. Це уявлення ототожнюе наш вузький світ зі світом узагалі, який тому сприймається лише як середовище, де ми мусимо орієнтуватися, а не як власна внутрішня значушість, яка передае смисл життя людини.

Проте всяка істота у світі - щось більше й інше, ніж усе, що ми про неї знаємо і якою ми її приймаємо; більше того-вона є щось більше й інше, ніж усе, що ми колись зможемо про неї дізнатися. Це випливае 3 розуміння буття як не просто змісту, а й змістового, не тільки даваного, а й такого, що дае. Трансраціональне буття постає у С. Франка як металогічна єдність - початок і кінець всякого окремого явища, як лоно, з якого виникає логічно розчленована сукупність окремих визначеностей, але яке саме не підпорядковане логічним принципам або законам і лежить глибше від них, утворюючи первинний шар реальності. Цей шар володіє якостями іррапіональності, індивідуальності, трансфінітності, невизначеності, становлення і свободи.

Заглибленість реальних предметів і явищ у металогічну єдність буття, їх нерозривний зв'язок із ним і неможливість існувати поза цією «живильною пуповиною» саме і надає конкретним об'єктам властиво- 
сті індивідуальності й свободи - на відміну від їх схематизованих образів, породжуваних раціоналістичним мисленням. Індивідуальність, за С. Франком, невідчутна в поняттях і в цьому розумінні тотожна з ірраціональністю - на противагу понятійному узагальненню, систематизації, множинності. Індивідуальність укорінена у всеєдності й тому виявляється там, де нас цікавить конкретна цілісність реальності, а не iï абстрагований зміст, що виражається в поняттях. «У конкретному змісті реальності безперечно відсутня множина» $[1$, с. 46$]$.

Потенційність і свобода випливають із невизначеності й становлення буття, яке не стоїть на твердому грунті, а немовби «переливається через край», постійно «виходить за межі самого себе», постійно породжуе щось нове, бо приховуе у своему лоні невизначеність. Виникаюче з'являеться не з раніше означеного буття, точніше сказати - не тільки 3 нього, але ще й $з$ трансфінітної сутності реальності, з темної глибини потенційного. Тому в становленні потенційність лише певною (або непевною) мірою пов'язана 3 якоюсь причиною, яка викликає відповідний наслідок, але в цьому причинно-наслідковому зв'язку завжди присутній елемент невизначеності. Це і є момент свободи. Буття в цілому може бути зрозумілим тільки як едність раціональності й ірраціональності, цебто необхідності та свободи. Тому в усьому конкретносущому (різною мірою) наявний і елемент первинної свободи.

Учення С. Франка про Неосяжне безперечно лежить у рамцях провідних мотивів філософії «срібного віку», мотивів конкректності та всеєдності. До нього цілком застосоване зауваження М. Лоського про те, що ідея конкретності стае метафізичним обгрунтуванням певної сопіально-етичної позиції, яка включае таке:

1. Ствердження абсолютної цінності конкретного, індивідуального буття, зокрема особистості.

2. Переконання, що цінність особистого буття стоїть на ранг вище від цінності абстрагованих начал.

3. Недопустимість поглинання особистості видом, родом, суспільством, державою, всесвітом.

4. Незвідність морального завдання особистості тільки до підпорядкування абстрагованим загальним правилам, законам і нормам, інакше кажучи, необхідність конкретної етики.

5. Учення про свободу в точному розумінні слова, цебто не тільки негативну відносну, а й позитивну абсолютну $[1$, с. 47$]$.

Справді, все вищесказане, що стосується кожної конкретної, внутрішньо цілісної реальності, в ще більшій мірі застосоване до людини як особистості. Особистість - духовна істота, яка має основу в без- 
конечності духовного царства, завжди за їі такою природою е щось більше й інше, ніж усе, що ми сприймаємо в ній як закінчену визначеність, «душевну конституцію». В цьому розумінні всі спроби якось класифікувати людей на кшталт метеликів або водоростей за якимись класами, рядами або расами завжди надто відносні. За такої класифікації ми відволікаємося, абстрагуємося від особистостей як таких, ми розкладаємо людину на соціальні категорії і поняття, вбиваючи тим самим її Індивідуальність. Це припустимо як допоміжний інструмент аналізу, але в жодному разі не як головний принцип, інакше можна прийти навіть до виправдання вбивства - i не фігурального, а фактичного (принцип колективної вини).

Особистість завжди індивідуальна, що виражаеться в їі безумовній єдності, незамінності, неповторності. Критикуючи індивідуалізм XVIII століття за його раціоналістичний підхід до особистості як абстрактної ідеї, символу рівноцінного і тотожного 3 іншими особистостями-символами, що, до речі, стало в остаточному підсумку філософською засадою соціалістичного руху, С.Франк протиставляє йому ідею, яка сягае корінням у німецький романтизм, конкретної і своерідної істоти. «Кожна особистість, - твердить він, - $е$ своєрідна і у своєму роді єдина істота» [5, с. 131]. Такий підхід дозволяе подолати обмеженість поведінкової, раціоналістичної моралі, зовнішнього морального імперативу, нав'язуваного особистості, виходячи з передумови їі рівноцінності з іншими. Моральний ідеал перебуває не в однорідності й рівності людей, а в розвитку самостійного духовного багатства, кожної індивідуальності. Різноманіття і оригінальність сприймаються не як зло, а як благо і мета особистості бачиться не в підпорядкуванні однаковим для всіх законів, а в здійсненні тих інтимних запитів і задатків, які в кожному різні й у кожному однаково верховні.

Така моральна філософія, яка виходить із абсолютного пріоритету внутрішнього, духовного життя, його неповторності близька до вчення $Ф$.Ніцше про надлюдину. Взагалі характерною рисою творчого становлення С.Франка є те, що обгрунтування невідчужуваних прав особистості він знаходить у філософії Ніцше, в його етичній системі «любові до дальнього» (етичного ідеалізму). Але при цьому С. Франк дуже чітко відрізняе цю мораль від уседозволеності. Адже він не заперечуе і не відкидає поведінкову мораль як таку - йдеться про вищий рівень етичної орієнтації, яка долає однобічність морального імперативу. Норми поведінки й стосунки між людьми С.Франк узагалі-то схильний залічувати до рівня правосвідомості (а не моралі), де діє принцип рівнозначності осіб. Їхнього рівного підлягання однаковим 
для всіх законам. А вище поведінкового рівня відкривається сфера духовного інтересу, прагнень і бажань, сфера власного морального права особистості реалізувати свою індивідуальність. У цій сфері діє вже принципово інший моральний імператив, орієнтований не на стосунки між людьми, а на духовне самоздійснення кожної людини, відповідальність перед собою: «Живи так, щоб зберігати душевну чистоту і повагу до самого себе» [5, с. 131-132]. Ідея рівності особистостей в їх безконечній, а тому і рівній цінності, доповнюеться ідеєю емпіричної нерівності, винятковості кожної безконечності, і в цьому розумінні різної практичної цінності окремих особистостей.

Разом 3 індивідуальністю особистість володіе свободою - справжнім осередлям духовного. Свобода у С. Франка $є$ онтологічною першоосновою людського життя, та єдиною точкою людського буття, в якій можливий безпосередній зв'язок людського з божественним. У свободі особистості здійснюеться їі належність до істинного буття, себто до Бога, їі боголюдяність, і одночасно - до емпіричного буття, сліпих природних сил. Боголюдяність не означае тотожності з Богом інакше це була б уже не особнстість, а якийсь гвинтик, інструмент абсолютної волі. 3 другого боку, емпіричність, поцейбічність «сама по собі» також не може надати існуванню смислу, бо будь-яке емпіричне діяння насправді е таким, що не має дійсної підстави, а людина стає іграшкою, рабом матеріальної необхідності $[1$, с. 49$]$.

\section{1 Бібліографія}

[1] Аляек Г. Метафізика особистості у філософії С. Франка // Філософська і соціологічна думка. - 1993. - № 3. - С. 43-56.

[2] Грот И.Я. Козлов. Философские этюды. (Критический очерк). K., 1977.

[3] Icmopiя філософії України : Підручник / М.Ф.Тарасенко, М.Ю.Русин та ін. - К.: Либідь, 1994.

[4] Плужнік $B$. Ідеї персоналізму в київській школі філософії. Олексій Козлов // Філософська і соціологічна думка. - 1995. - № 1 2.- C. $138-158$.

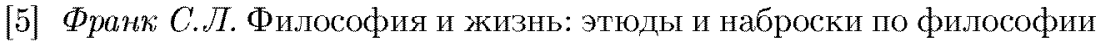
культуры. - СПб, 1910. 